\title{
Pengaruh Gaya Penggunaan Anggaran, Kompleksitas Tugas, Kompleksitas Organisasi Dan Dukungan Manajemen Terhadap Hubungan Strategi Cost Leadership Dan Peningkatan Kinerja di PT Perkebunan Nusantara Xi (Persero)
}

\section{Suwandhi*}

\section{Abstract}

This study aims to examine whether the program of cost leadership affects the labours' performance of PT Perkebunan Nusantara $X I$ (Persero) . Contingency approach is widely used by researchers to determine whether the success of the companies affected by the cost leadership strategy and always have the same effect in each condition. To explain these effects, this study uses four contingency factors, the use of budgets, task complexity, organizational complexity and management support in cost control program in PT Perkebunan Nusantara XI ( Persero).

The method of data collection is survey methods by using Moderated Regression Analysis (MRA) to test the hyphotesis. The results of the study is that budget, task complexity, organizational complexity and management support is not a moderating variable that can strengthen the relationship between cost leadership programs and the improvement of performance in PT PTPN XI (Persero).

The results of this study are expected to contribute to the practitioners and to anticipate factors that may affect the company's performance. For academics, these are to explain, how, when, and where the use of the budget, the task complexity, the organization complexity and management support required in order to improve relationship between cost leadership program and the organization success influenced by different conditions.

Keywords : cost leadership - task complexity - organization complexity style use of the budget - management support

*Dosen LPP Pertanian Yogyakarta 


\section{Pendahuluan}

Manajemen memerlukan strategi sebagai alat untuk memenangkan persaingan dan mempertahankan kelangsungan hidup perusahaan. Strategi merupakan pola keputusan dan tindakan tertentu yang memungkinkan manajer mencapai tujuan organisasi (Hill dan Jones, 1998). Perusahaan kadangkala melakukan perubahan strategi bisnis yang telah dijalankan untuk beradaptasi dengan lingkungan industrinya. Perusahaan dalam memasuki persaingan yang ketat akan. menerapkan strategi bersaing agar dapat tetap bertahan, strategi yang diterapkan akan disesuaikan dengan corecompetencies yang dimiliki dan kondisi yang dimiliki perusahaan (Hax dan Majiuf, 1995).

Kunci yang selalu menjadi andalan bagi sebagian besar organisasi untuk mampu bertahan adalah keunggulan bersaing. Organisasi perusahaan pada umumnya mampu memperoleh keunggulan persaingan jika posisi yang dimiliki mampu memberi kekuatan yang menonjol di atas kekuatan pesaing dan kemampuannya untuk pengembangan image produk perusahaan terhadap pelanggan (product positioning). Menurut Porter (1980), terdapat dua bentuk strategi besar atau strategi generik yang dapat dipergunakan perusahaan dalam bersaing yaitu costleadership dan 
differentiation. Masing-masing strategi tersebut dijadikan dasar bagi perusahaan untuk mempertahankan keunggulan kompetetitip dan mendifinisikan potensi yang dapat dikembangkan dalam organisasi. Kesuksesan penerapan masing-masing strategi dipengaruhi oleh sumber daya, ketrampilan, desain organisasi dan sistem kontrol yang dimiliki oleh perusahaan.

Untuk menjamin bahwa strategi yang telah ditetapkan oleh perusahaan diimplementasikan dan menghasilkan output atau kinerja sesuai dengan yang diharapkan maka perusahaan harus membangun sistem pengendalian manajemen. Anthony dan Govindarajan (2001) menyebutkan sistem pengendalian manajemen merupakan proses yang mana manajer mempengaruhi anggota organisasi yang lain untuk mengimplementasi strategi organisasi. Aktivitas yang ada dalam pengendalian manajemen meliputi perencanaan, koordinasi, komunikasi dan evaluasi. Sistem pengendalian manajemen akan mempengaruhi perilaku manusia baik melalui proses formal (misalkan perencanaan_strategik, penganggaran dan pelaporan) maupun non formal (seperti etika kerja, gaya manajemn, dan kultur).

Penelitian sebelumnya yang dilakukan oleh J. Lee dan Miller (1999) meneliti tentang pengaruh strategi kompetitif terhadap hubungan antara komitmen organisasi kepada karyawan dengan kinerja keuangan. Menurut Triyono Budiwibowo dan Arfan Ikhsan (2003) penelitian di Indonesia menunjukkan adanya perbedaan temuan tentang pengaruh strategi kompetitif terhadap hubungan 
antara komitmen organisasi kepada karyawan hubungannya dengan kinerja perusahaan. Satriawan (2002) menemukan bahwa perusahaan dengan strategi costleadership dan strategi diferentiation tidak berpengaruh positip dan signifikan terhadap kinerja. Penelitian Wahyuningsih (2002) menumakan bahwa perusahaan yang menggunakan costleadership berpengaruh positip dan signifikan pada kinerja, sedangkan untuk strategi differntiation ditemukan tidak signifikan terhadap kinerja.

Berdasarkan penelitian Wahyuningsih (2002), peneliti yakin cost leadership berpengaruh pistip dan signifikan terhadap kinerja. Untuk itu pada penelitian ini, peneliti mencoba memperluas pengujian terhadap tiga viariabel, yaitu dukungan manajemen puncak, penggunan anggaran, dan metode pengendalian biaya sebagai pemoderasi costleadership pengaruhnya terhadap kinerja di PT Perkebunan Nusantara XI (persero). Penelitian ini berbeda dengan penelitian sebelumnya karena menggunakan tiga variabel pemoderasi, dengan $=$ pengukuran dan obyek penelitian yang berbeda_dengan sebelumnya.

PT Pérkebunan Nusantara XI (Persero) sebagai salah satu sumber keuangan negara adalah Badan Usaha Milik Negara (BUMN) yang mempunyai 2 (dua) Unit Usaha dan 16 (enam belas) Pabrik Gula, wilayah kerjanya tersebar di karesidenan Madiun, Pasuruan, Probolinggo, Lumajang, Bondowoso dan Situbondo di Propnsi Jawa Timur. Perusahaan tersebut dipilih menjadi obyek penelitian karena wilayah kerjanya yang terpencar, memiliki sumberdaya yang tidak sedikit dạ permasalahannya kompleks, strategi usahanya tetap memantapkan usaha pokok melalui peningkatan produktivitas dan $=$ - $\therefore \quad$ overall cost leadership untuk memperoleh harga pokok produksi yang 
kompetitif dan menghasilkan produk dengan mutu sesuai permintaan pasar.

Berdasarkan uraian pada latar belakang masalah yang ada pada bab pendahuluan, maka pokok masalah yang akan diteliti adalah:

1) Apakah strategi cost leadership berpengaruh terhadap kinerja di PT Perkebunan Nusantara XI (Persero)?

2) Apakah dukungan manajemen berpengaruh terhadap hubungan antara CostLeadership dengan kinerja di PT Perkebunan Nusantara XI (Persero)?

3) Apakah gaya penggunaan anggaran berpengaruh terhadap hubungan antara CostLeadership dengan kinerja di PT Perkebunan Nusantara XI (Persero)?

4) Apakah kompleksitas tugas berpengaruh terhadap hubungan antara CostLeadership dengan kinerja di PT Perkebunan Nusantara XI (Persero)?

5) Apakah kompleksitas organisasi berpengaruh terhadap hubungan antara CostLeadership dengan kinerja di PT Perkebunan Nusantara XI (Persero)?

\section{Tinjauan Teoritis dan Hipotesis}

\section{Keunggulan Bersaing}

Beberapa ahli berpendapat bahwa kunci keunggulan kompetitif suatu perusahaan adalah kualitas sumber daya manusia yang berada didalamnya, keberhasilan perusahaan akan sangat bergantung kepada kemampuannya untuk mengembangkan dan mengelola sumberdaya yang dapat diandalkan untuk bersaing dilingkungan bisnis yang kompetitif dan leverage pada sumber daya yang mampu 
menempatkan perusahaan pada posisi daya saing dalam jangka panjang. Sumberdaya manusia memiliki kemampuan untuk menjadi faktor pembeda. Perusahaan dalam persaingan melalui kemampuannya dalam menerapkan pengetahuan dalam pekerjaan mereka (Ulrich, 1998 dalam Triyono B. Dan Arfan Ikhsan, 2003).

\section{Konsep Strategi}

Porter (1985) menggambarkan tiga strategi generik yang berbeda pada level bisnis yaitu: costleadership, differentation dan focus. Ketiga strategi generik Porter sebagai basis keuntungan persaingan yang berkelanjutan.

Miles dan Snow dalam Siti Musyarofah (2003) melihat tipe strtaegi tidak berdasrkan pada level strategi melainkan pada tingkat perubahan orientasi pasar dan produk. Ada empat tipe strategi bisnis yang diidentifikasi oleh Miles dan Snow (1978) menurut tingkat perubahan-produk maupun pasar, yaitu: prospectors, defenders, analyzer dan reactor.

Hill dan Jones (1998) mendifinisikan perubahan strategik sebagai pergerakan dari apa yang dilakukan saat ini menuju ke yang dilakukan di masa depan untuk meningkatkan keuntungan persaingan. Perubahan strategik yang dilakukan dapat berupa: (1) reengineering (2) restructuring dan (3) innovation.

Porter (1985) menguraikan dua strategi kopetitif generik, yaitu: overallcostleadership dan differentiation. Berikut ini dijelaskan strategi generik menurut Porter yang akan digunakan dalam penelitian ini. 
a. Strategi Overall Cost Leadership

Strategi overall cost leadrship, -- berusaha untuk meningkatkan pangsa pasar dengan menekankan lowcost dibanding dengan pesaing. Secara umum strategi low costleadership sangat baik untuk perusahaan yang lebih besar yang mampu mengambil keuntungan dari skala ekonomi, akses yang lebih besar terhadap sumberdaya dan overhead yang lebih rendah, dapat menghasilkan biaya per unit yang lebih rendah secara keseluruhan (Porter, 1985).

Dengan demikian dapat disimpulkan bahwa cost leadership akan berpengaruh pada peningkatkan kinerja perusahaan/organisasi. Sehingga dapat dirumuskan hipotesis kedua sebagai berikut:

H1: Strategi cost leadership, akan berpengaruh terhadap kinerja perusahaan.

b. Strategi Differentiation.

Strategi generik, yang kedua adalah differntiation. Perusahaan mencapai keunggulan bersaing melalui pemberian produk atau jasa yang menawarkan kualitas yang unik yang diinginkan oleh customer. Perusahaan yang mengadopsi strategi differntiation biasanya memiliki target pembeli yang tidak sensitif terhadap harga tinggi dan perusahaan tersebut sering mempunyai pangsa pasar yang rendah secara relatif. Strategi differntiation yang berhasil di backed up dengan banyak aktivitas yang berbiaya tinggi, seperti riset yang ekstensif, desain produk dan pengeluaran pemasaran (Miller dan Friesen, 1986). 
c. Kinerja Perusahaan

Para peneliti menyetujui bahwa pengukuran kinerja bisnis perusahaan tidak cukup menggunakan satu ukuran tunggal, karena tidak dapat menggambarkan tingkat pencapaian prestasi perusahaan sesungguhnya. Pengukuran kinerja bisnis dapat menggunakan ukuran seperti: sales, sales growth, market share growth, ROI (Return on Invesment) atau ROA (Return on Asset), ROI Growth, ROS (Return on Sales), ROS growth asset (Ittner dan Larcker, 1997). Dalam penelitian ini menggunakan indikator Becker dan Gerhad (1996), dikarenakan kompetensi, dan kompenasi bukan hanya ukuran keuangan, namun dirasa pula pada produktivitas, komplain konsumen pada perusahaan, kerusakan mesin, dan kegagalan produk.

\section{Variabel Pemoderasi}

a. Dukungan Manajemen

Pengendalian tidak hanya-dicapai melalui proses formal tetapi juga nonformal yang menekankan hubungan satu individu dengan individu yang lain, antara orang yang mengendalikan dan orang yang dikendalikan memiliki hubungan sosial. Menurut Blake dan Mouth (dalam Hopwood, 1976) solusi terhadap masalah yang muncul dalam lingkungan organisasional yang kondusip untuk meningkatkan kinerja dan kepuasan yang tinggi terletak pada pola hubungan sosial yang dikenal dengan gaya manajemen (style ofmanagement).

Cerullo (1980) dalam Choe (1996) menyatakan bahwa dukungan manajemen puncak meliputi penyusunan sasaran atau penilaian tujuan, mengevaluasi usulan proyek pengembangan, melakukan review program dan pengembangan sistem informasi. Choe (1996) mengutip pendapat Doll (1985) menyatakan bahwa 
dukungan manajemen puncak meliputi jaminan pendanaan dan menentukan prioritas. Menurut Muntoro (1994), dukungan manajemen puncak tidak hanya penting untuk alokasi sumber daya yang diperlukan, melainkan memberi strong signal bagi karyawan bahwa perubahan yang dilakukan merupakan sesuatu yang penting.

b. Penggunaan Anggaran

Beberapa penelitian sebelumnya lebih menekankan peran anggaran secara tradisional sebagai alat diagnostik (Simons, 1990) sementara Burchell et al, (1980) menyebut peran anggaran sebagai "answer machine". Peran anggaran sebagai sistem pengendalian telah berubah tidak hanya sebagai alat diagnosa, melainkan sebagai mesin dialog, pembelajaran dan penciptaan ide-ide oragnisasi (Burchell, 1980) sejalan dengan hal itu Simons menyebutnya sebagai peran interaktif.

Lebih tegas (Anthony dan Govindrajan, 2001, Simons, 2002) menyebutkan bahwa sistem pengendalian diagnostik merupakan sistem informasi formal yang digunakan oleh manajer untuk memonitor outcomes organisasi dan melakukan tindakan koreksi atas penyimpangan dari standar yang telah ditetapkan. Sementara sistem pengendalian interaktif adalah sistem informasi formal yang memungkinkan manajer melibatkan dirinya secara personal dalam pengambilan keputusan oleh bawahan. Sistem ini menurut Simons untuk mengantisipasi ketidakpastian strategik yang dihadapi oleh organisasi. Dalam penelitian ini akan digunakan gaya penggunaan anggaran diagnostik dan interaktif sebagaimana yang dikemukakan oleh Simons dan Anthony. 


\section{c. Kompleksitas Organisasi dan Tugas}

Kompleksitas merupakan akibat langsung dari pembagian pekerjaan dan pembentukan departemen yang focus pada jumlah dan jenis pekerjaan, pengelompokan jabatan, jumlah unit atau departemen yang berbeda secara nyata (Gibson, Ivancevich dan Donnelly, 1997). Organisasi dengan berbagai jenis pekerjaan dan unit menimbulkan masalah manajerial dan organisasi yang lebih rumit karena terjadi ketergantungan tugas dan sifat tugas yang senakin kompleks. Thompson (1967) dan lam Diana (2003) menyatakan bahwa kompleksitas dalam organisasi akan menimbulkan ketergantungan tugas diantara individu yang ada dalam tiap departemen dan masalah koordinasi semakin kuat, sehingga memerlukankolaborasi dan mutual adjusmen lebih besar melalui anggota tim. Ketergantungan tugas membutuhkan kolaborasi masing-masing anggota dalam tim atau kelompok (Ggladstein, 1984). Pada organisasi yang lebih kompleks menunjukkan bahwa tugas dan pekerjaan yang dilakukan semakin rumit sehingga memerlukan pemanfaatan knowledge dan solusi yang tepat atas pekerjaan yang diselesaikan (Perrow, 1972)

Scott dan Tiessen (1999) mendifinisikan keterlibatan tim (pengawal program costleadership) sebagai waktu yang dicurahkan oleh anggota tim untuk melakukan pekerjaan dalam interdepartemen- -dan intra departemen. Lingkungan yang dinamik dan komplek memerlukan pembuatan keputusan yang cepat, pendekatan fleksibel, pekerjaan berdasarkan knowledge serta proses intensif capital (lawler, 1993). Pada kondisi tersebut memerlukan keterlibatan pekerja yang sangat tinggi dalam organisasi melalui pembentukan tim. Pembentukan tim akan mendukung mekanisme integrasi dalam organişasi yang lebih flat (mendatar) karena akan mendelegasikan otoritas péfinbuatan 
keputusan pada level hirarki organisasi lebih rendah. Tim dapat bersifat formal yang akan mendukung keberadaan struktur organisasi untuk menunjang koordinasi, integrasi dan inovasi dalam organisasi (Cohen, 1993) dalam Nur Diana (2003). Tim yang bersifat informal mempunyai tugas co-location, menetapkan jaringan kerja antar personil, atau melakukan rotasi individu melalui multiple discipline (Diana, 2003), sedangkan tim yang bersifat formal bertugas untuk merespon dalam rangka elemen integrasi berbeda dan membantu inovasi organisasi.

Hasil penelitian Scott dan Tiesen (1988) menunjukkan bahwa adanya tugas yang semakin kompleks dan tidak pasti, memerlukan individu yang mempunyai keahlian bidang dan fungsi yang berbedabeda, sehingga dapat memecahkan persolan yang dihadapi secara memadai. Untuk itu diperlukan keterlibatan pekerja dalam interdepertemen tim. Sedangkan adnya ketergantungan tugas yang sangat tinggi melibatkan intra departemen tim. Berdasarkan teori dan temuan empiris yang diperoleh maka hipotesis yang diajukan adalah:

H4: Tugas yang semakin kompleks dalam penerapan strategi cost leadership, akan meningkatkan pengaruh cost leadership terhadap. kinerja perusahaan.

Hubungan antara Cost Leadership, Dukungan Manajemen dan Kinerja Perusahaan

Breckhard dan Pritchard (1992) dalam Siti Musyarofah (2003) menyatakan terdapat tiga faktor penting dalam memfungsikan organisasi, yaitu: leadership, culture dan management of change. 
Kegagalan perubahan organisasi menurut mereka disebabkan oleh kurangnya perhatian terhadap aspek budaya kepemimpinan.

Pemimpin yang menghadapai karakteristik pekerjaan yang relatif terstruktur maka akan mengandalkan superioritasnya dalam organisasi yang mengarah pada dimensi intiating structure. Sementara jika pemeimpin menghadapai karakteristik pekerjaan yang relatif tidak tersestruktur maka ia akan mengandalkan kemampuannya untuk memberikan inspirasi dan memotivasi bawahan yang mengarah pada consideration (Fieddler, 1970) dalam Siti Musyarofah (2003).

Temuan riset Boonstra dan Vink (1996) seperti dikutip Hamlin, et al (2001) dalam Siti Musyarofah (2003) dalam studi pada perusahaan kliring dan keuangan menyebutkan hambatan terbesar dalam inovasi teknis dan organisasional adalah kepemimpinan yang bersifat autocratic dan kualitas kepemimpinan dalam merespon perubahan.

Hamlin, et al (2001) melakukan survey terhadap 814 manajer dari berbagai level dalam organisasi tentang pengaruh restructuring terhadap kinerja organisasi dan perilaku pegawai. Hasilnya menunjukkan bahwa restructuring mempunyai dampak cukup besar terhadap kinerja organisasi/perusahaan.

Dengan demikian dapat disimpulkan bahwa dukungan manajemen akan memberikan kontribusi pada perubahan strategik dalam rangka meningkatkan kinerja perusahaan/organisasi. Sehingga dapat dirumuskan hipotesis kedua sebagai berikut:

$\mathrm{H} 2$ : Dukungan manajemen yang tinggi dalam penerapan strategi cost leadership, akan meningkatkan pengaruh cost leadership terhadap kinerja perusahaan. 
Hubungan antara Cost Leadership, Penggunaan Anggaran dan Kinerja Perusahaan

Kapabilitas pemrosesan transaksi akan meningkat jika ditunjang. oleh struktur organik dimana komunikasi lebih bersifät informasi lateral dan vertikal (Mintzberg, 1983). Simons (1990) menyebutkan bahwa penggunaan anggaran yang bersifat interaktif memberikan sarana bagi manajemen puncak untuk memahami nilainilai dan preperensi individu, alat untuk memperdebatkan bagaimana merespon perubahan lingkungan dan kondisi operasi. Macintosh (1994) menyebutkan bahwa anggaran lebih berperan sebagai alat kompromi dari pada sebagai "answer machine"

Penggunaan anggaran secara interaktif tidaklah murah, hal ini menuntut keterlibatan top manajemen secara intensif dalam proses anggaran termasuk meningkatkan interaksi antar anggota organisasi. Penggunaan anggaran secara interaktif akan meningkatkan kinerja ketika perubahan strategik yang terjadi relatif tinggi. Sebaliknya penggunaan anggaran diagnostik akan efektif ketika perubahanstrategik yang terjadi rendah. Penelitian Abemethy dan Bronwell (1999) tentang peran anggaran dalam perubahan strategik berhasil mengkonfirmasi bahwa perubahan strategik akan terpengaruh lebih positif terhadap kinerja ketika perusahaan menggunakan anggaran secara interaktif.

Dengan demikian hipotesa penelitian yang diusulkan sebagai berikut:

H3: Semakin tinggi pengendalian penggunaan anggaran, akan semakin meningkatkan pengaruh cost leadership terhadap kinerja perusahaan. 


\section{Metode Penelitian}

\section{Metode Pemilihan Sampel dan Pengumpulan Data}

Responden penelitian ini adalah para administratur, kepala bagian, para RC, mandor, operator, dan juru tulis Pabrik Gula di Wilayah kerja PTP Nusantara XI (Persero). Pertanyaan yang diajukan kepada responden meliputi seberapa besar partisipasi mereka dalam penggunaan anggaran, persepsi mereka terhadap dukungan manajemen puncak, metode pengendalian biaya yg digunakan, dan manfaat cost leadership bagi Pabrik Gula.

Metode pengumpulan data yang digunakan adalah metode survei, data dikumpulkan menggunakan kuesioner yang dibagikan langsung pada saat lokakaryaCostleadership disetiap Pabrik Gula. Untuk kepentingan analisis dengan statistik, peneliti menentukan jumlah minimal 100 responden setiap Pabrik Gula. Sedangkan di wilayah kerja PT Perkebunan Nusantara XI (Persero) ada 16 Pabrik Gula, 1 Pabrik Alkohol dan Spiritus, dan 1 Pabrik Karung Goni dan Plastik.

\section{Pengujian Validitas dan Reliabilitas}

$\therefore$ Ketepatan pengujian suatu hipotesis tergantung pada kualitas yang dipakai pada penelitian tersebut. Penelitian tidak akan berguna jika instrument yang digunakan untuk mengumpulkan data tidak memiliki reliabilitas dan validitas yang tinggi (Cooper dan Emory, 1995). Ujireliabilitas data dilakukan uji konsistensi internal dengan koefisien Cronbach Alpha, menggunakan c

kriteria relibilitas di atas atau sama dengan 60\% (Nunnaly, 1978). Instrumen yang koefisennya di bawah $60 \%$ dianggap memiliki relibilitas rendah. Sedangkan uji validitas dilakukan dengan person correlation, 
dengan criteria valid bila semua butir kuesioner signifikan. Kuesioner dikatakan valid jika pertanyaan pada kuesioner mampu untuk mengungkapkan sesuatu yang akan diukur oleh kuesioner tersebut (Ghozali, 2001).

\section{Pengujian Nonresponse Bias}

Pengujian nonresponbias dilakukan untuk mengetahui apakah ada perbedaan karakteristik sample dari responden yang menjawab dan responden yang tidak menjawab. Dari dua kelompok jawaban tersebut dilakukan pengujian $t$-test.

\section{Metode Analisis Data}

Untuk menguji hubungan antara Cost Leadership dan keberhasilan Pabrik Gula digunakan Analisis Regresi Sederhana, sedangkan untuk pemoderasi digunakan Moderated Regression Analysis (MRA).

Untuk menguji pengaruh Cost Leadership terhadap Keberhasilan Pabrik Gula digunakan Simple Regression Analysis. Sedangkan untuk menguji pengaruh variabel -pemoderasian digunakan Moderated Regression Analysis (MRA). Dalam menerapkan MRA, persamaan statistik yang digunakan untuk menentukan variabel pemoderasian dalam hubungan antara Cost Leadership. dan keberhasilan Perusahaan sebagai berikut:

Dalam menerapkan MRA, persamaan statistika yang digunakan untuk menentukan variabel pemoderasian dalam hubungan antara Cost Leadership dan keberhasilan Pabrik Gula Soedhono, dinyatakan dalam persamaan sebagai berikut:

$$
\begin{aligned}
& Y=a+b_{1}+b_{2} \cdot X_{2}+b_{3} \cdot X_{3}+b_{4} \cdot X_{4}+b_{5} \cdot X_{5}+b_{6} \cdot X_{1} X_{2}+b_{7} \cdot X_{1} X_{3} \\
& +b_{8} \cdot X_{1} X_{4}+b_{9} \cdot X_{1} X_{5}+6_{10} \cdot X_{1} X_{2} X_{3} X_{4} X_{5}+e
\end{aligned}
$$




\section{Dimana:}

Y: Keberhasilan PTP Nusantara XI (Persero), $X_{1}$ : Cost Leadership, $X_{2}$ : Anggaran, $\mathrm{X}_{3}$ : Kompleksitas Tugas, $\mathrm{X}_{4}$ : Kompelsitas Organisasi, $\mathrm{X}_{5 \text { : }}$ Dukungan Manajemen, a: Intercept b: Slope

\section{Hasildan Pembahasan}

\section{Deskripsi Responden}

$\therefore$ Profil 1.749 responden yang berpartisipasi dalam penelitian ini ditunjukkan dalam tabel 1. Data profil responden menunjukkan bahwa $1 \%$ mempunyai jabatan administratur, $4 \%$ mempunyai jabatan kepala bagian, $18 \%$ RC/Masinis/Kemiker/Sinder, $20 \%$ mempunyai jabatan mandor/pemegang kebun, sedangkan jabatan operator/juru tulis sebanyak $43 \%$, sedang $15 \%$ lain-lain.

Untuk pendidikan responden menunjukkan bahwa dari keseluruhan responden tidak ada yang berpendidikan S3 dan S2. Sedangkan S1 sebanyak 9\%, berpendidikan D3 atau sederajat sebanyak $4 \%$, SLA sebanyak $74 \%$, dan $13 \%$ berpendidikan lain-lain.

Latar belakang pendidikan responden menunjukkan $47 \%$ berlatar belakang teknik dan pengolahan, $17 \%$ berlatarbelakang pendidikan pertanian/teknologi pertanian, $17 \%$ responden berlatar belakang ekon̄omi/hukum, $20 \%$ berlatarbelakang lain-lain.

Sedang pengalaman kerja responden menunjukkan $4 \%$ mempunyai pengalaman kerja kurang dari 5 tahun, 16\% mempunyai pengalaman 5 - 10 tahun $17 \%$ mempunyai pengalaman kerja $11-15$ tahun dan 64\% mempunyai pengalaman lebih dari 15 tahun.

Dari profil responden terlihat bahwa pendidikan dan jabatan responden cukup memadai. Hal ini memberikan jaminan diberikannya 
respon yang dapat memenuhi isi kuesioner, dan diharapkan dapat memberikan kontribusi dalam penelitian ini.

\section{Hasil Pengujian Hipotesis}

Pada uji interaksi disiapkan data interaksi antara variabel cost leadership dengan masing-masing variabel pemoderasi. Interaksi antara cost leadership dengan variabel anggaran dinyatakan dalam variabel moderat1. Interaksi antara cost leadership dengan kompleksitas tugas dinyatakan dalam variabel moderat2. Interaksi antara cost leadership dengan kompleksitas organisasi dinyatakan dalam variabel moderat3. Interaksi antara cost leadership dengan dukungan manajemen dinyatakan dalam variabel moderat4. Interkasi antara cost leadership dengan anggaran, kompleksitas tugas, organisasi dan dukungan manajemen puncak dinyatakan dalam variabel moderat5.Strategi cost leadership, akan berpengaruh terhadap kinerja perusahaan.

Hasil analisis regresi sederhana menunjukkan besarnya Adjusted $R$ Square 0,078 hal ini berarti hanya 7,8\% keberhasilan PT Perkebunan Nusantara XI (Persero) yang dapat dijelaskan oleh variabel Cost Leadership. Hasil pengujian dapat dilihat pada tabel 2.

Tabel 2. Hasil Simple Regression Analysis

\begin{tabular}{|r|c|r|r|r|r|}
\hline Model & $\mathbf{R}$ & R Square & $\begin{array}{c}\text { Adjusted R } \\
\text { Square }\end{array}$ & $\begin{array}{c}\text { Std. Error of } \\
\text { the Estimate }\end{array}$ & Durbin-Watson \\
\hline $\mathrm{I}$ & .280 & .078 & .078 & .54833 & 1.723 \\
\hline
\end{tabular}

a Predictors: (Constant), COSTLEAD-- . .

b Dependent Variable: KEPUASAN- .

Dapat disimpulkan model dalam penelitian ini reliable dan dapat digunakan. Hal ini ditunjukkan dengan uji signifikansi simultan (uji-F statistik) pada tabel 3. Uji signifikansi simultan (uji F Statistik) pada tabel 
3. menghasilkan nilai $F$ hitung sebesar 148,100 dengan tingkat signifikansi pada $p$-value 0,000 . Ini menunjukkan probabilitas signifikansi lebih kecil dari 5\%, maka dapat dikatakan Cost Leadership, berpengaruh pada keberhasilan PT Perkebunan Nusantara XI (Persero).

Tabel 3. Hasil Pengujian Signifikasi Simultan (Uji F Statistik)

\begin{tabular}{|r|r|r|r|r|r|}
\hline \multicolumn{1}{|l|}{ Móddel } & \multicolumn{1}{|c|}{$\begin{array}{c}\text { Sum of } \\
\text { Squares }\end{array}$} & \multicolumn{1}{|c|}{ Df } & $\begin{array}{c}\text { Mean } \\
\text { Square }\end{array}$ & F & Sig. \\
\hline 1 Regression & 44.529 & 1 & 44.529 & 148.100 & .000 \\
Residual & 525.262 & 1747 & .301 & & \\
Total & 569.790 & 1748 & & & \\
\hline
\end{tabular}

a Predictors: (Constant), COSTLEAD

b Dependent Variable: KEPUASAN

Apabila dilihat uji signifikansi parameter individual (uji $t$ statistik) pada tabel 4. variabel COSTLEAD juga signifikan, dengan memberikan $t$ value 12,170 dengan tingkat signifikansi pada $p$-value 0,000 .

Tabel 4. : Hasil Pengujian Signifikasi Individual (Uji t Statistik)

\begin{tabular}{|c|c|c|c|c|c|}
\hline & \multicolumn{2}{|c|}{$\begin{array}{l}\text { Unstandardized } \\
\text { Coefficients }\end{array}$} & $\begin{array}{l}\text { Standardized } \\
\text { Coefficients }\end{array}$ & $\mathbf{t}$ & Sig. \\
\hline Model & B & $\begin{array}{c}\text { Std. } \\
\text { Error }\end{array}$ & Beta & & \\
\hline I (Constant) & 2.931 & .089 & & 33.070 & .000 \\
\hline COSTLEAD & .294 & .024 & .280 & 12.170 & .000 \\
\hline
\end{tabular}

a Dependent Variable: KEPUASAN

Sedangkan hasil analisis MRA besamya Adjusted $R$ Square 0,288 yang berarti $28,8 \%$ variasi keberhasilan PT Perkebunan Nusantara XI (Persero) dapat dijelaskan oleh variasi variabel independen Cost Leadership dan moderatnya. Hasil pengujian dapat dilihat tabel 5 
Tabel 5. Hasil Moderated Regression Analysis (MRA)

\begin{tabular}{|r|c|r|c|c|}
\hline Model & R & R Square & $\begin{array}{c}\text { Adjusted R } \\
\text { Square }\end{array}$ & $\begin{array}{c}\text { Std. Error of the } \\
\text { Estimate }\end{array}$ \\
\hline 1 & .540 & .292 & .288 & .48170 \\
\hline
\end{tabular}

a Predictors: (Constant), MODERAT5, DUKUNGAN, KOMPLEKS, COSTLEAD,

ORGANISA, ANGGARAN, MODERAT2, MODERAT4, MODERATI, MODERAT3

Dengan uji signifikansi simultan (uji F Statistik) pada tabel 6. menghasilkan nilai $F$ hitung sebesar 79,627 dengan tingkat signifikansi pada p-value 0,000. Ini menunjukkan probabilitas signifikansi lebih kecil 5\%, maka dapat dikatakan Cost Leadership, dan moderatnya secara bersama-sama berpengaruh pada keberhasilan PT Perkebunan Nusantara XI (Persero).

Tabel 6. Hasil Pengujian Signifikansi Simultan (Uji F Statistik)

\begin{tabular}{|r|r|r|r|r|r|r|}
\hline Model & & Sum of Squares & Df & Mean Square & F & \multicolumn{1}{l|}{ Sig. } \\
\hline 1 & Regres & 166.285 & 9 & 18.476 & 79.627 & .000 \\
\hline & Residual & 403.505 & 1739 & .232 & & \\
\hline & Total & 569.790 & 1748 & & & \\
\hline
\end{tabular}

\section{ANOVA}

a Predictors: (Constant), MODERAT5, DUKUNGAN, KOMPLEKS, COSTLEAD, ORGANISA, ANGGARAN, MODERAT2, MODERAT4, MODERATI, MODERAT3

b Dependent Variable: KEPUASAN

Apabila dilihat uji signifikansi parameter individual (uji t statistik) pada tabel 7. variabel ANGGARAN tidak signifikan memberikan $t$-value 2.409 dengan tingkat signifikansi pada $p$-value 0,016 . Struktur organisasi tidak signifikan, memberkan $t$-value --.411dengan tingkat signifikansi pada $p$-value 0,681 , kompleksitas tugas tidak signifikan, memberkan $t$ - 
value 0,790 dengan tingkat signifikansi pada p-value 0,429 , Keterlibatan manajemen signifikan, memberikan $t$-value 2,845 tingkat signifikansi pada p-value 0,004 . Semakin tinggi pengendalian penggunaan anggaran, akan semakin meningkatkan pengaruh cost leadership terhadap kinerja perusahaan.

Hipotesis kedua yang diajukan semakin tinggi pengendalian penggunaan anggaran, akan semakin meningkatkan pengaruh cost leadership terhadap kinerja perusahaan secara statistik dapat ditolak. Hal ini dibuktikan dengan hasil variabel moderatl yang merupan interaksi antara cost leadership dengan penggunaan anggaran hasilnya tidak signifikan tidak signifikan dengan memberikan t-value -1,592 dengan tingkat signifikansi pada p-value 0,112 dan koefisien beta sebesar 7.706E-02. Artinya hipotesis alternatif pertama yang diajukan secara statistik tidak berhasil didukung secara signifikan karena $p$-value lebih kecil dari alpha ( $\mathrm{p}$-value $<0,05$ ). Hasil ini konsisten dengan penelitian yang dilakukan oleh Siti Musyarofah (2003) dinyatakan bahwa gaya penggunaan anggaran tidak memoderasi hubungan antara perubahan strategik dengan kinerja organisasiSemakin tinggi kompleksitas tugas, akan:semakin meningkatkan pengaruh cost leadership terhadap kinerja perusahaan.

Pada tabel 7 dapat dilihat, variabel moderat2 yang merupakan interaksi antara cost leadershipdengan kompleksitas tugas, hasilnya tidak signifikan dan memberikan $t$-value 2,657 dengan tingkat signifikansi pada p-value 0,008.dan koefísen beta. sebesar 9.830E-02. Ini menunjukkan hipotesis kedua juga tidak didukung secara statistik, karena nilai $p$-valuenya lebih kecil dari tingkat keyakinan (confidence interval) yang $5 \%$. 
Artinya tidak ada hubungan antara kompleksitas tugas dengan program cost leadership untuk mencapai kinerja perusahaan.

Semakin tinggi kompleksitas organisasi, akan semakin meningkatkan pengaruh cost leadership terhadap kinerja perusahaan.

Variabel moderat3 merupakan interaksi antara Cost Leadership dengan kompleksitas organisas, hasilnya tidak signifikan dengan memberikan $t$-value -.635 dengan tingkat signifikansi pada $p$-value 0,526 dan koefisen beta sebesar $-3.490 \mathrm{E}-02$. Terbukti tidak ada pengaruh kompleksitas organisasi dalam pengendalian biaya terhadap hubungan cost leadership dengan keberhasilan perusahaan, karena nilai p-value lebih kecil dari tingkat keyakinan $5 \%$ (p-value $<0,05)$. Artinya hipotesis ketiga secara statistik tidak didukung pada penelitian ini.Dukungan manajemen yang tinggi dalam penerapan strategi cost leadership, akan meningkatkan pengaruh cost leadership terhadap kineja perusahaan.

Variabel moderat4 merupakan interaksi antara Cost Leadership dengan dukungan manajemen; - tidak signifikan dengan memberikan $t$ value -.632 dengan tingkat signifikansi pada p-value 0,528. dan koefisen beta sebesar $-3.311 E-02$. Terbukti juga tidak ada pengaruh dukungan manajemen dalam pengendalian biaya terhadap hubungan cost leadership dengan keberhasilan perusahaan, karena nilai $p$-value lebih kecil dari tingkat keyakinan $5 \%$. (p-value $<0,05)$. Artinya hipotesis keempat secara statistik tidak didukung.pada penelitian ini. Hal ini tidak konsisten dengan penelitian yang dilakukan oleh Kim dan Lee (1986), Sunarti dan Nur Indriantoro (1998), Elfreda Aplonia Lau (2003) dinyatakan bahwa dukungan manajemen memoderasi hubungan antara perubahan strategik dengan kinerja organisasi. 
Pengendalian anggaran, kompleksitas tugas, organisasi dan dukungan manajemen yang tinggi dalam penerapan strategi cost leadership, akan meningkatkan pengaruh cost leadership terhadap kinerja perusahaan.

Variabel moderat5 merupakan interaksi antara Cost Leadership dengan gaya penggunaan anggaran, kompleksitas tugas, kompleksitas organisasi dan dukungan manajemen, tidak signifikan dengan memberikan $t$-válue 1,058 dengan tingkat signifikansi pada $p$-value 0,290 dengan koefisien beta sebesar 4.475E-05. Artinya variabel gaya penyusunan anggaran, kompleksitas dan struktur organisasi bukan variabel pemoderasi yang memperkuat hubungan antara Cost Leadership dengan keberhasilan PT Perkebunan Nusantara XI (Persero).

Tabel 7. Hasil Pengujian Signifikansi Individual (Uji t Statistik)

\begin{tabular}{|l|r|r|r|r|r|}
\hline & \multicolumn{3}{|l|}{ Unstandardized Coefficients } & $\begin{array}{c}\text { Standardized } \\
\text { Coefficients }\end{array}$ & \multicolumn{1}{l|}{ Sig. } \\
\hline Model 1 & $\mathrm{B}$ & Std. Error & \multicolumn{1}{c|}{ Beta } & & \\
\hline (Constant) & 1.498 & 1.019 & & 1.470 & .142 \\
\hline ANGGARAN & .377 & .157 & .389 & 2.409 & .016 \\
\hline KOMPLEKS & -.170 & .412 & -.161 & -.411 & .681 \\
\hline ORGANISA & .142 & .179 & -.111 & .790 & .429 \\
\hline DUKUNGAN & .432 & .152 & .482 & 2.845 & .004 \\
\hline MODERAT1 & $-7.706 \mathrm{E}-02$ & .048 & -.464 & -1.592 & .112 \\
\hline MODERAT2 & $9.830 \mathrm{E}-02$ & .037 & .675 & 2.657 & .008 \\
\hline MODERAT3 & $-3.490 \mathrm{E}-02$ & .055 & -.172 & -.635 &. .526 \\
\hline MODERAT4 & $-3.311 \mathrm{E}-02$ & .052 & -.213 & -.632 & .528 \\
\hline MODERAT5 & $4.475 \mathrm{E}-05$ & .000 & .154 & 1.058 & .290 \\
\hline
\end{tabular}

a Dependent Variable: KEPUASAN 


\section{Kesimpulan}

Berdasarkan hasil pengujian hipotesis menggunakan analisis regresi berganda sebagaimana telah dibahas sebelumnya dapat disimpulkan beberapa hal sebagai berikut:

a. Program Cost leadership (pengendalian biaya) yang diduga berpengaruh pada kinerja perusahaan didukung oleh hasil analisis pada penelitian ini. Hasil analisis regresi sederhana menunjukkan besarnya Adjusted $R$ Square 0,078 hal ini berarti hanya 7,8\% keberhasilan PT Perkebunan Nusantara XI (Persero) yang dapat dijelaskan oleh variabel Cost Leadership. Sedangkan hasil analisis MRA besarnya Adjusted $R$ Square 0,288 yang berarti 28,8\% variasi keberhasilan PT Perkebunan Nusantara XI (Persero) dapat dijelaskan oleh variasi variabel independen Cost Leadership dan moderatnya.

b. Penggunaan anggaran yang diduga menjadi variabel pemoderasi yang dapat mempengaruhi hubungan antara cost leadership dengan keberhasilan PT Perkebunan Nusantara XI (Persero) tidak didukung dalam penelitian ini. Koefisien interaksi antara çost leadership dengan penggunaan anggaran 0.0377 dengan $t$-value 2.409 dengan tingkat signifikasi pada $p$-value 0.016 . Hal ini konsisten dengan penelitian yang dilakukan oleh Siti Musyarofah (2003) dinyatakan bahwa gaya penggunaan anggaran tidak memoderasi hubungan antara perubahan strategik dengan kinerja organisasi.

c. Kompleksitas tugas yang diduga menjadi variabel pemoderasi yang dapat mempengaruhi hubungan antara cost leadership dengan keberhasilan PT Perkebunan Nusantara XI (Persero) juga tidak didukung dalam penelitian ini. Koefisien interaksi antara cost leadership dengan kompleksitas tugas $9.830 \mathrm{E}-02$ dengan $t$-value 2.657 dengan tingkat signifikasi pada $p$-value 0.008 . 
d. Kompleksitas organisasi yang diduga menjadi variabel pemoderasi yang dapat mempengaruhi hubungan antara cost leadership dengan keberhasilan PT Perkebunan Nusantara XI (Persero) juga tidak didukung dalam penelitian ini. Koefisien interaksi antara cost leadership dengan kompleksitas organisasi $-3.490 \mathrm{E}-02$ dengan $t$-value -0.635 dengan tingkat signifikasi pada p-value 0.526 .

e. Dukungan manajemen yang diduga menjadi variabel pemoderasi yang dapat mempengaruhi hubungan antara cost leadership dengan keberhasilan PT Perkebunan Nusantara XI (Persero) juga tidak didukung dalam penelitian ini. Koefisien interaksi antara cost leadership dengan dukungan manajemen $-3.311 \mathrm{E}-02$ dengan $t$-value 0.632 dengan tingkat signifikasi pada p-value 0.528 . Hal ini tidak konsisten dengan penelitian yang dilakukan oleh Kim dan Lee (1986), Sunarti dān Nur Indriantoro (1998), Elfreda Aplonia Lau (2003) dinyatakan bahwa dukungan manajemen memoderasi hubungan antara perubahan strategik dengan kinerja organisasi.

f. Pengendalian anggaran, kompleksitas tugas, kompleksitas organisasi - dan dukungan manajemen secara bersama yang diduga menjadi variabel pemoderasi yang dapat mempengaruhi hubungan antara cost leadership dengan keberhasilan PT Perkebunan Nusantara XI (Pềrsero) juga tidak didukung dalam penelitian ini. Koefisien interaksi antara cost leadership dengan variabel pemoderasi tersebut $4.475 \mathrm{E}-02$ dengan $t$-value 1.058 dengan tingkat signifikasi pada $p$-value 0.290 .

\section{Keterbatasan}

Sampel yang digunakan pada penelitian ini terbatas pada penggunaan sampel pada PT Perkebunan Nusantara XI (Persero), yang 
memungkinkan akan mengurangi kemampuan hasil penelitian ini untuk digeneralisasi pada semua subyek penelitian.

Pengisian kuesioner. mungkin tidak se;perti diharapkan, kerena responden salah persepsi atas pertanyaan yang dihadapi atau tidak serius dalam memberikan jawaban. Hal ini dapat menyebabkan kesimpulan menjadi bias.

Instrumen yang digunakan untuk mengukur penggunaan anggaran hanya dibentuk oleh lima pertanyaan, meskipun syarat validitas dan reliabilitas suatu instrument telah dipenuhi tidak menutup kemungkinan instrument tersebut kurang menunjukkan keseluruhan dimensi dari variable yang dirancang.

\section{Implikasi}

Cost leadership tetap harus dipertimbangkan, bagaimana dan kapan diperlukan, sehingga pengendalian harga pokok produksi dapat ditekan serendah mungkin dan kinerja perusahaan dapat dicapai. Hasil penelitian ini' juga memberikan konstribusi literature pada akuntansi manajemen yang menjelaskan hubungan antara strategi costleadership dẹngan peningkatan kinerja perusahaan dengan menggunakan sifat hubungan yang dipengaruhi oleh kondisi yang berbeda.

\section{Saran}

- Perlu dipikirkan. untuk mengembangkan instrument yang benarbenar " mampu menguji program cost leadership terhadap kinerja perusahaan. Diharapkan penelitian ini dapat mendorong peneliti selanjutnya untuk meneliti variable lain. 


\section{DAFTAR PUSTAKA}

Anthony, $\mathrm{R}$ dan Govindarajan, 2001, management Control System, Mc Graw-Hill International Edition.

Becker, B. Gerhart, B. 1996, The Impact of Human Resources Management on Organizational performance: Progress and Prospects. Academy of management Jurnal, 39 (4): 779-801

Choe; Jong-Min, 1996, "The Relationship Among Perfornance of Accounting Information Systems, Influence Factors, and Evolution Level of Information Systems," Journal of Management Information Systems. Vol 12, No. 4. Spring.

Cooper, R.D., dan C. William Emory, 1995, Business research Methods, Five Edition, Richard D. Irwin, Inc.,

Elfreda Aplonia Lau, 2003, "Pengaruh Partisipasi Pemakai Terhadap kepuasan Pemakai Dalam Pengembangan Sistem Informasi Dengan Lima Variabel Moderasi," proceding Simposium Nasional Akuntansi VI, Surabaya.

Hopwood, A. (1976), accounting and Human Behavior, Prentice-Hall Inc, -Eglewood Cliff New Jersey.

Ittner, C.D., D.F. Larcker dan M.V. Rajan, 1997 The Choice of Performance Measures in Annual Bonus Contracts. The Accounting Review, 72 (2) hal. 231-255.

Miller, D. dan P.H. Friesen, 1986, Innovation in Conservative and Entrepreneural Firm: Two Models of Strategic Momentum, Strategic Management Journal, hal. 125

Muntoro R.K., 1994, The use of Organization Behavior Methods in The Development of Computerized Accounting System in Indoensia: An Attitudial Survey, Ph.D. Dissertation, Accontancy Development in Indoensia Publication.

Nunnaly, J.C.dan I.H., Bemsten,1994. Psycometric Theory, McGrawHill,3th. Ed. 
Nur Diana, 2003, “Analisis Hubungan Kompleksitas Organisasi, Keterlibatan Tim, diversitas Ukura Kinerja, Besar kompensasi, Partisipasi terhadap Kinerja Tim," Proceding Simposium Nasional Akuntansi VI, Surabaya

Porter, M.E, 1985, Competitive Advanted, free, Press New York.

Simons, R. 1990, The Role of Management Control Systems in Creating Competitive Advantage, New Perspective, Accounting Organization and Society,

Siti Musyarofah, 2003, "Pengaruh Penggunaan Anggaran dan Gaya manajemen Terhadap Hubungan Antara Perubahan Strategik dan Kinerja Organisasi,"Proceding Simposium Nasional Akuntansi VI, Surabaya

Triyono Budiwibowo dan Arfan Ikhsan, "Pengaruh Strategik Kompetitif, Motivasi dan Budaya Kerja Terhadap Hubungan Antara Komitmen Organisasi Kepada Karyawan Dengan Kinerja Perusahaan", . Proceding Simposium Nasional Akuntansi $V$, Surabaya 
Aidha Trisanty, Kepuasan Nasabah Pada PT.Bank Tabungan Negara...

.

$=$

$\therefore=$ 